\title{
The main drivers of methane emissions differ in the growing and flooded fallow seasons in Mediterranean rice fields
}

\author{
Maite Martínez-Eixarch (D) - Carles Alcaraz • Marc Viñas • Joan Noguerol • \\ Xavier Aranda • Frances-Xavier Prenafeta-Boldú • Mar Català-Forner • \\ M. Siobhan Fennessy • Carles Ibáñez
}

Received: 2 July 2020 / Accepted: 14 December 2020 / Published online: 9 January 2021

(C) The Author(s) 2021

\begin{abstract}
Purpose To assess 1) the cumulative greenhouse gas emissions -GHG- and global warming potential (methane $-\mathrm{CH}_{4}$ - and nitrous oxide) from rice fields in the growing and fallow seasons, and 2) the environmental and agronomic drivers of $\mathrm{CH}_{4}$ emissions, and their relative capacity to explain $\mathrm{CH}_{4}$ variation.

Methods A two-year multisite field experiment covering the agronomic and environmental variability of a rice growing area in NE Iberian Peninsula was conducted with monthly samplings of GHG and monitoring of both environmental and agronomic factors. Information-
\end{abstract}

Responsible editor: Zucong Cai

M. Martínez-Eixarch $(\bowtie) \cdot$ C. Alcaraz $\cdot$ C. Ibáñez

IRTA Institute of Agrifood Research and Technology, Marine and Continental Waters, Ctra. Poble Nou, km. 5.5, 43540 Sant Carles de la Ràpita, Spain

e-mail: maite.martinezeixarch@irta.cat

M. Viñas · J. Noguerol · F.-X. Prenafeta-Boldú

IRTA Institute of Agrifood Research and Technology, GIRO.

Torre Marimon, 08140 Caldes de Montbui, Spain

X. Aranda

IRTA Institute of Agrifood Research and Technology,

Fruticulture. Torre Marimon, 08140 Caldes de Montbui, Spain

M. Català-Forner

IRTA Institute of Agrifood Research and Technology, Extensive crops. Ctra. Balda km 1, 43870 Amposta, Spain

M. S. Fennessy

Biology Department, Kenyon College, Gambier, OH 43022, USA theoretic framework analysis was used to assess the relative contribution of the environmental and agronomic variables on methane emissions.

Results Two thirds of the $\mathrm{CH}_{4}$ is emitted in the fallow season. Edaphic factors exert more influence during the growing season whereas agronomic factors have a higher impact in the fallow. The implications of these findings on the design of improved mitigation options rice are discussed.

Conclusions Soils with higher soil sulphate concentration, bulk density and clay content emit less $\mathrm{CH}_{4}$ in growing season. In the fallow season, the rates of both straw input and nitrogen fertilization stimulate $\mathrm{CH}_{4}$ emissions.

Keywords Greenhouse gas emissions · Paddy rice .

Post-harvest season - Seasonal methane emissions .

Straw management . Soil sulfate content

\begin{tabular}{ll}
\multicolumn{2}{l}{ Abbreviations } \\
$\mathrm{CH}_{4}$ & methane \\
$\mathrm{DOC}$ & dissolved organic carbon \\
$\mathrm{GHG}$ & greenhouse gas \\
$\mathrm{GLMz}$ & generalized linear models \\
$\mathrm{GWP}$ & global warming potential \\
$\mathrm{N}$ & nitrogen \\
$\mathrm{NUE}$ & nitrogen use efficiency \\
$\mathrm{N}_{2} \mathrm{O}$ & nitrous oxide \\
$\mathrm{SO}_{4}{ }^{2-}$ & sulphate \\
$\mathrm{SOM}^{-}$ & soil organic matter \\
$\mathrm{SP}$ & selection probability
\end{tabular}




\section{Introduction}

Anthropogenic greenhouse gas (GHG) emissions associated with agricultural production has increased $81 \%$ (from $3.1 \mathrm{Gt} \mathrm{CO}_{2}$-eq $\mathrm{yr}^{-1}$ to $5.8 \mathrm{Gt} 17 \mathrm{CO}_{2}$-eq $\mathrm{yr}^{-1}$ ) during the period 1961-2016 (IPCC 2019). The increase from agricultural activities is primarily due to methane $\left(\mathrm{CH}_{4}\right)$ emissions from paddy rice fields (Schaefer et al. 2016) which contribute $48 \%$ of cropland greenhouse gas emissions (Carlson et al. 2017). Because this flux is such a substantial portion of the global methane budget, it represents a large potential for GHG mitigations (IPCC 2019).

Methane emissions from paddy rice agroecosystems are a function of overall $\mathrm{CH}_{4}$ production, oxidation, and release to the atmosphere (Cai et al. 2007). A suite of biologic, environmental and agronomic factors modulates the dynamics of $\mathrm{CH}_{4}$ emissions. Soil microbiota contributes substantially to GHG emissions through concurrent $\mathrm{CH}_{4}$ production and consumption processes in the soil. Anaerobic soils of paddy rice provide the proper environmental conditions for anaerobic bacteria and methanogenic archaea, thriving syntrophically on the degradation of soil native or plant-derived organic carbon (Conrad 2007). Nevertheless, a substantial fraction of $\mathrm{CH}_{4}$ is oxidized by methanotrophic bacteria at the anoxic-oxic interfaces at the soil surface and in the rhizosphere (Watanabe et al. 1997), and also by anaerobic methane-oxidizing community (Nauhaus et al. 2005). The remaining $\mathrm{CH}_{4}$ surplus is eventually released to the atmosphere, primarily through the aerenchyma of the rice plants (Cicerone and Shetter 1981; Laanbroek 2010). Consequently, the physiological traits of the rice plants and the associated crop management (e.g., flooding) are key factors in $\mathrm{CH}_{4}$ emissions by providing a carbon source and anoxic environment to methanogens (Lu and Conrad 2005; Tokida et al. 2011) as well as an oxidative interface for the methanotrophs (Jiang et al. 2017).

Fertilization and crop residue management are, under permanent flooding conditions, major agronomic factors affecting $\mathrm{CH}_{4}$ emissions in rice paddy fields (Linquist et al. 2018). Nitrogen fertilization has been widely studied but results on the net impact on $\mathrm{CH}_{4}$ emissions have been mixed (Wassmann et al. 1993; Banik et al. 1996; Shang et al. 2011) while in the case of sulphate fertilizers, there is a general consensus that they can reduce $\mathrm{CH}_{4}$ emissions (Rath et al. 1999; Denier van der Gon et al. 2001; Minamikawa et al. 2005). The straw that remains in the field after the rice harvest is important for the overall $\mathrm{CH}_{4}$ emissions and carbon budget because, depending on its management, it represents a large input of organic matter available for soil decomposing microorganisms. There are a variety straw management practices implemented worldwide, such as removal, mulching, composting, burning and incorporation into the soil; the selection is crop-context dependent. Finally, edaphic factors, mainly soil texture, are also relevant. There is wide consensus that coarser soil textures lead to higher emissions (Sass et al. 1994; Brye et al. 2013, 2016). However, soil texture is closely linked to rice productivity (Dou et al. 2016), fertilizer use efficiency of the crop (Alhaj Hamoud et al. 2019) and agricultural practices since farmers adapt their management to soil conditions. Therefore, the effect of soil texture favouring the gas diffusivity can be modulated by the agronomic management and the performance of the crop.

The interaction of these biological, environmental and, agronomic factors confers a complex system regulating $\mathrm{CH}_{4}$ dynamics that yields variable cumulative emissions across and within the different rice growing areas. Addressing these processes individually may fail in both identifying the main processes responsible for net $\mathrm{CH}_{4}$ emissions and provide realistic and precise estimations of the emissions. In spite of this, only a few studies have used a multivariate approach to assess GHG emissions in rice agroecosystem (e.g. Jia et al. 2002; Yan et al. 2005; Brye et al. 2016; Knox et al. 2016), but in most cases analyses were not controlled for collinearity among variables.

While $\mathrm{N}_{2} \mathrm{O}$ emissions from continuously flooded rice fields are widely accepted to be negligible or small (Linquist et al. 2015; Wang et al. 2016) there are some managements, mainly related to nitrogen fertilization and water management that can induce $\mathrm{N}_{2} \mathrm{O}$ pulses (Cai et al. 1997; Kritee et al. 2018; Lagomarsino et al. 2016; Pittelkow et al. 2013). Further, the warming potential of this gas is 298 times as high as that of $\mathrm{CO}_{2}$ (Smith et al. 2014). Then, it is necessary to assess $\mathrm{N} 2 \mathrm{O}$ emissions to accurately estimate global warming potential of rice fields.

To address such complexity a two-year field study was conducted in a Mediterranean rice growing area in the Ebre Delta (Catalonia, Northeaster Spain) based on a farm-to-farm approach covering the whole range of agronomic and environmental variability of the area. In a previous paper resulting from this study (Martínez- 
Eixarch et al. 2018), we identified the key dynamic variables modulating $\mathrm{CH}_{4}$ fluxes, including environmental (soil physic-chemical parameters such as temperature, $\mathrm{pH}$, redox and conductivity) and agronomic (water level, plant cover) factors. In the present report, we focus on the relative effect of static factors (rather than dynamic) on cumulative (rather than fluxes) greenhouse gas emissions and the resulting global warming potential. Therefore, the main objectives set for the present report were to study the effect of static features (i.e. soil properties), agronomic management (i.e. fertilizer rates and straw incorporation), and productive traits (i.e. plant density, panicle density, and grain yield) on cumulative GHG emissions, including both $\mathrm{CH}_{4}$ and $\mathrm{N}_{2} \mathrm{O}$. We applied a multivariate analysis and an information theoretic approach to find the best explanatory model. This approach allowed us to control for variables collinearity and calculate the relative importance of each independent variable in GHG emissions.

\section{Material and methods}

\section{Study area}

Rice production in Spain accounts for $28 \%$ and $5 \%$ of the European production and crop extension, respectively, while in the Ebre Delta (Catalonia, NE Spain), it covers 21,125 ha, representing ca. $19 \%$ of the total rice growing area in Spain (Spanish Ministry of Agriculture, Food and Environment).

The climate of the region is Mediterranean with a mean annual precipitation of about $500 \mathrm{~mm}$, mostly distributed during spring and autumn. The mean annual air temperature is $18^{\circ} \mathrm{C}$, ranging from $23^{\circ} \mathrm{C}$ to $27^{\circ} \mathrm{C}$ during the rice growing season (May to September) and from $6{ }^{\circ} \mathrm{C}$ to $13^{\circ} \mathrm{C}$ during the post-harvest (October to December).

Rice cultivation in the Ebre Delta is divided in three periods: pre-sowing (January to early April), growing (late April to September) and post-harvest (October to December) seasons. The fields are left fallow over the post-harvest and pre-sowing seasons. This study covers the growing and post-harvest seasons.

Water management follows an annual pattern, with fields permanently flooded over the growing season to a depth ca. 5 to $15 \mathrm{~cm}$ deep. In the post-harvest season, fields are either flooded or left to progressively drain, according to the farmers' preferences, but even if the latter is the case, fields remain flooded and then soil- saturated for most of this season, as straw addition is practiced in flooded conditions (puddling). Finally, fields are dry over the pre-sowing season because the irrigation supply from the canal network is cut off in December.

Soil operations are conducted in the dry pre-sowing season, i.e., harrowing and fertilizer application. The average mineral nitrogen fertilizer application rates range from 170 to $200 \mathrm{~kg} \mathrm{~N} \mathrm{ha}^{-1}$. Irrigation from the hydraulic network is provided from mid-April, then fields are flooded, and water seeded from late April to mid-May. The cultivars used in the area are Japonicatype with medium grain size and a growth cycle of ca. 120 and 140 days (from sowing to maturity). For this study, fields grown with two representative cultivars in the area, Gleva or JSendra, were selected. The harvest is conducted over the month of September, and it is followed by incorporation of the straw into the soil, mainly in October, which is the standard residue management.

\section{Experimental layout}

Experiments were conducted over the growing (June to September) and post-harvest seasons (October to December) in 2015 and 2016. Because $\mathrm{CH}_{4}$ emissions were the priority of this study, samples were not collected during the pre-sowing season, when the fields are dry and emissions are minimal, in order to focus the sampling effort on the flooded or soilsaturated periods, when methane emission is expected. Furthermore, negligible $\mathrm{CH}_{4}$ emission rates were found in May of 2015 (Martínez-Eixarch et al. 2018), so that, for the sake of optimizing resources, in the second year of the study gas sampling was started in June.

Hereafter, the post-harvest season will be referred as the flooded fallow season to stress both uncultivated and flooded conditions of the rice fields in this period. A total of 24 commercial rice fields (15 in 2015 and 9 in 2016), following standard agricultural management of the area, were selected for the study. Sites were widely distributed over the Ebre Delta (Fig. 1) to capture the environmental (soil properties and salinity, proximity to either river, sea, or lagoons) and agronomic (water management, phytosanitary applications and agronomic performance) variability of the area. 


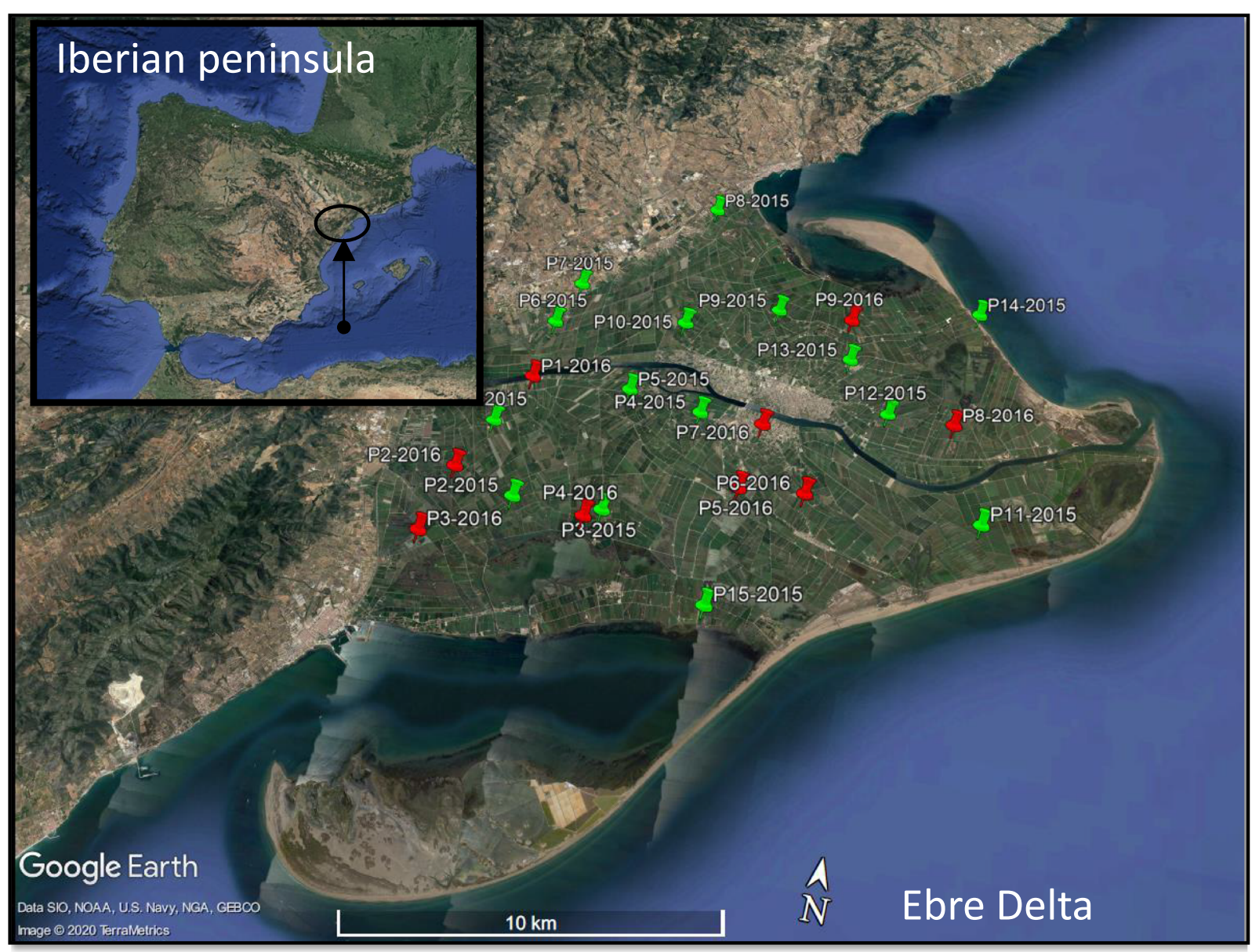

Fig. 1 Location of the 24 rice fields in Ebre Delta monitored in year 2015 (in green) and 2016 (in red)

Gas sampling and flux measurement

Gas sampling was conducted on a monthly basis, using non-steady state gas chambers (Altor and Mitsch 2008; Weishampel and Kolka 2008). The characteristics of the chambers as well as the procedure for chamber deployment and field sampling plan are detailed in MartínezEixarch et al. (2018). In brief, the chambers, were made of polyvinylchloride (PVC) structure covered by transparent plastic and they were equipped with a thermometer to monitor temperature within the chamber in each extraction. To avoid soil disturbance during gas sampling, blocks were installed in the field to support wooden boards to access the chamber. All the rice fields were sampled within the same day and consistently from 10:00 am to $3: 00 \mathrm{pm}$ to minimize variability derived from the daily emission variation (Hatala et al. 2012). During the sampling procedure, each gas sample was transferred overpressured to pre-evacuated $12.5 \mathrm{~mL}$ vials (Labco Ltd., Buckinghamsire, UK) and sent to laboratory. Methane $\left(\mathrm{CH}_{4}\right)$ and nitrous oxide $\left(\mathrm{N}_{2} \mathrm{O}\right)$ concentration was determined using a THERMO TRACE 2000 (Thermo Finnigan Scientific, USA) gas chromatograph equipped with a flame ionization detector (GC-FID). Analysis of $\mathrm{N}_{2} \mathrm{O}$ were carried out using an Agilent 7820A GC System, (Agilent, USA) equipped with an electron capture detector (GC-ECD). The calibration of the gas chromatograph was carried out using a $\mathrm{CH}_{4}$ and $\mathrm{N}_{2} \mathrm{O}$ standard in nitrogen provided by Carburos Metalicos S.A. (Spain).

The emission rates of the GHG, i.e. $\mathrm{CH}_{4}$ and $\mathrm{N}_{2} \mathrm{O}$, were obtained from the change of concentration of the respective gas in chambers over the 30-min sampling period in each chamber. The emission rate was estimated by the slope of the linear regression between gas concentration and sampling time. The increase of temperature in the headspace of the chamber was considered to correct GHG concentration of each sample 
according to the ideal gas law. Only significant linear regressions $\left(P<0.05\right.$ and $\left.R^{2}>0.80\right)$ were accepted, and non-significant regressions were considered as zero emission rates.

Monthly mean emissions rates and cumulative emissions in each field were calculated assuming constant emission rates over the entire month. Seasonal (growing and fallow seasons) and total (from June to December) cumulative GHG were calculated by summing monthly cumulative emissions. The overall global warming potential (GWP), including $\mathrm{CH}_{4}$ and $\mathrm{N}_{2} \mathrm{O}$, was estimated using the IPCC factors, i.e. 25 and 298, respectively, over the 100-year time scale (Smith et al. 2014).

Climatic, edaphic, and agronomic measurements

\section{Environmental and edaphic traits}

Climatic data was obtained from a meteorological station located in Ebre Delta (Municipality of Amposta; GPS coordinates, 40.708; 0.632) belonging to the Web of Agrometeorological Stations of Weather Services of Catalonia (Catalan Government).

In March, before flooding, a soil composite three sub-samples per field was extracted for soil characterization: texture (USDA characterization), soil granulometry (\% of clay, sand and silt) and dry bulk density (by granulometry), content of organic matter, sulphates, and nitrogen (by Spectrometry).

\section{Agronomic management and crop production traits}

Agricultural practices, including fertilization (source, timing and rates), water (hydroperiod and water layer depth) and straw (rate and time of straw input) management, and agronomic traits (plant and panicle density, grain yield (of the current and preceding growing cycle) in each field was recorded according to farmer's communication. In 2015, the time of straw incorporation was broadly monitored by registering whether this practice was done or not the day of gas sampling. In 2016, given the relevance of post-harvest emissions observed in the preceding year, more detail was registered by surveying the farmers. Plant $\mathrm{d}$ and panicle density was assessed by IRTA staff by counting plants and panicles in 10 to 15 delimited subareas of $0.25 \mathrm{~m}^{2}$ each, distributed along a diagonal transect of the field. Grain yield of the current and preceding season was used as a proxy of the rate of straw input, assuming a mean harvest index of 0.5 (Matías et al. 2019).

\section{Statistical analysis}

Generalized Linear Models (GLMz) were used to study the association between cumulative GHG emissions and agroecological factors based on an information-theoretic approach to find the best approximating models (Tabachnick et al. 2007). GLMz were built including all possible combinations of independent variables, but excluding interactions, due to the large number of variables considered. The models meeting the following criteria were accepted as candidates: significant improved performance in relation to the null model and variance inflation factor of $\leq 5$, in order to avoid multicollinearity effects in regression models (Maggini et al. 2006). The second order Akaike information criterion (AICc), rescaled to obtain $\triangle \mathrm{AICc}$ values $(\triangle \mathrm{AICc}=\mathrm{AICci}-$ minimum $\mathrm{AICc})$ was performed to evaluate the degree of support of each candidate model. Further details on the criteria for the selection of the models are provided in Aparicio et al. (2018). Prior to the analysis, quantitative variables were transformed to improve linearity and homoscedasticity. Analyses were performed with the R software version 3.4.

\section{Results}

Climatic data

Climatic data are presented in Fig. 2. Mean annual and seasonal temperatures followed similar values and temporal variation over the two years of the study. The mean annual temperature was $16.5 \pm 1.1^{\circ} \mathrm{C}$ with highest mean maximum thresholds recorded in July and August. The mean temperature during the growing season (from May to September) was on average 8 degrees higher $\left(22.0 \pm 0.8^{\circ} \mathrm{C}\right)$ than during the flooded fallow (October to December: $\left.13.9 \pm 1.5^{\circ} \mathrm{C}\right)$. Cumulative rainfall was higher in $2015(445.0 \mathrm{~mm})$ than in $2016(376.0 \mathrm{~mm})$ yet seasonal distribution differed in the two years with more precipitation in the growing season of 2015 but less in 2016 compared to the flooded fallow. 


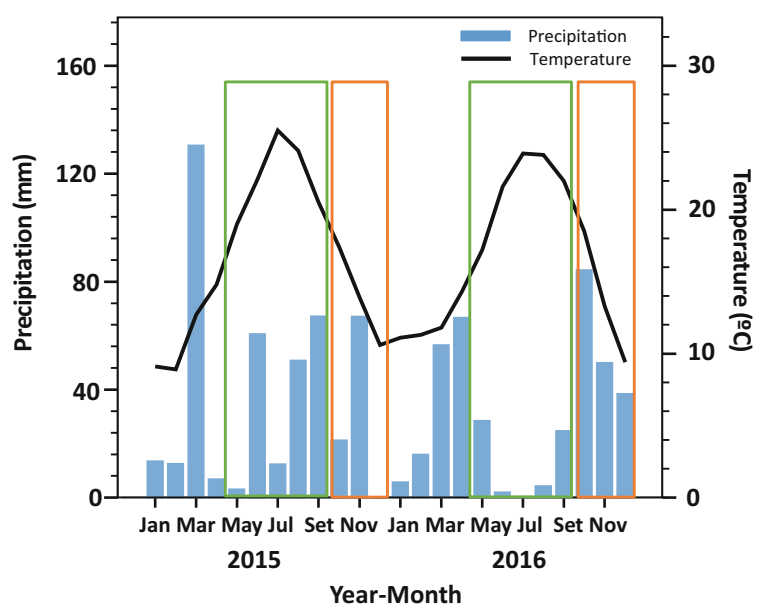

Fig. 2 Monthly mean temperatures and cumulative precipitation over the two years of the study (2015-2016). Rectangles represent the period of greenhouse sampling during the growing (green) and fallow (brown) seasons

Agronomic and soil characteristics of the rice fields

Agronomic and soil characteristics of the 24 monitored rice fields used in the study are detailed in Table 1.

Soil characteristics varied among rice fields as shown by the different soil textures, wide ranges of bulk density (809-1041 $\left.\mathrm{kg} \mathrm{m}^{-3}\right)$, soil organic matter (1.89-7.70\%), nitrogen $(0.11-0.36 \%)$, sulphate $\left(1928-6439 \mathrm{mg} \mathrm{kg}^{-1}\right)$, and the percent clay (11.3-36.7\%) and sand (6.3$84.6 \%$ ). Grain yield ranged from 5814 to $9897 \mathrm{~kg}$ paddy rice $\mathrm{ha}^{-1}$. Rice fields yielded on average less in 2015 $\left(7759.3 \pm 255.4 \mathrm{~kg}\right.$ paddy rice $\left.\mathrm{ha}^{-1}\right)$ than in 2016 $\left(8225.0 \pm 698.5 \mathrm{~kg}\right.$ paddy rice $\left.\mathrm{ha}^{-1}\right)$ whereas the opposite pattern was found for panicle density (chronologically: $352.9 \pm 12.2$ vs. $303.0 \pm 10.3$ panicles $\mathrm{m}^{-2}$ ). Rates of $\mathrm{N}$ fertilization were similar in the two years (chronologically: 172.6 and $175.7 \mathrm{~kg} \mathrm{~N} \mathrm{ha}^{-1}$ ) but substantially lower sulphate fertilization rates were applied in $2016\left(24.4 \pm 5.6 \mathrm{~kg} \mathrm{~S} \mathrm{ha}^{-1}\right)$ than in $2015(72.2 \pm$ $9.4 \mathrm{~kg} \mathrm{SO}_{4}{ }^{2-} \mathrm{ha}^{-1}$ ).

Total GHG emissions and global warming potential

In total, rice fields in Ebre Delta emitted $262.6 \pm 5.9 \mathrm{~kg}$ $\mathrm{CH}_{4} \mathrm{~m}^{-2} \mathrm{ha}^{-1}$ (two-year mean) of which $36.9 \%$ was emitted during the growing season $\left(96.6 \pm 2.8 \mathrm{~kg} \mathrm{CH}_{4}\right.$ $\mathrm{ha}^{-1}$ ) and $63.1 \%$ during the flooded fallow season $\left(163.9 \pm 9.8 \mathrm{~kg} \mathrm{CH}_{4} \mathrm{ha}^{-1}\right)$ mainly in October. October alone accounted for $45.4 \%$ of the annual emissions.
The monthly $\mathrm{CH}_{4}$ emissions rates followed a bimodal pattern (Fig. 3) with the first peak occurring in August $\left(4.7 \pm 0.3 \mathrm{mg} \mathrm{CH}_{4} \mathrm{~m}^{-2} \mathrm{~h}^{-1}\right)$ and the second, and the highest, in October $\left(15.7 \pm 2.0 \mathrm{mg} \mathrm{CH}_{4} \mathrm{~m}^{-2} \mathrm{~h}^{-1}\right)$. The mean emission rate in the growing season was almost identical over the two years of the study (chronologically: $3.4 \pm 0.1,3.2 \pm 0.2 \mathrm{mg} \mathrm{CH}_{4} \mathrm{~m}^{-2} \mathrm{~h}^{-1}$ ). By contrast, mean emission rate in the flooded fallow season was higher in $2015\left(8.7 \pm 0.6 \mathrm{mg} \mathrm{CH}_{4} \mathrm{~m}^{-2} \mathrm{~h}^{-1}\right.$ vs. $5.3 \pm 0.4 \mathrm{mg} \mathrm{CH}_{4} \mathrm{~m}^{-2} \mathrm{~h}^{-1}$ ) because of the larger peak in October $\left(16.8 \pm 3.0\right.$ vs. $\left.15.7 \pm 2.0 \mathrm{mg} \mathrm{m}^{-2} \mathrm{ha}^{-1}\right)$ and the more progressive decline thereafter.

The overall cumulative annual $\mathrm{N}_{2} \mathrm{O}$ emissions were negative, $-0.33 \pm 0.02 \mathrm{~kg} \mathrm{~N}_{2} \mathrm{O} \mathrm{ha}^{-1}$, resulting in monthly emission rates that were negligible or negative (ranging from $-0.003 \mathrm{mg} \mathrm{N}_{2} \mathrm{O} \mathrm{m}{ }^{-2} \mathrm{~h}^{-1}$ to $0.028 \mathrm{mg} \mathrm{N}_{2} \mathrm{O}$ $\mathrm{m}^{-2} \mathrm{~h}^{-1}$ (Fig. S1).

The resulting global warming potential (GWP) of rice fields in the Ebre Delta, which integrates both $\mathrm{CH}_{4}$ and $\mathrm{N}_{2} \mathrm{O}$ emissions, was $6466.7 \pm 147.9 \mathrm{~kg} \mathrm{CO}_{2}-$ eq $\mathrm{ha}^{-1}$. Only $\mathrm{CH}_{4}$ emission contributed to GWP.

Drivers of seasonal $\mathrm{CH}_{4}$ emissions: growing and flooded fallow seasons

The information-theoretic framework analyses to provide predictive models of the effects of the agronomic and soil-treat variables on $\mathrm{CH}_{4}$ emissions (Table 2) were applied for the growing and flooded fallow seasons.

We selected 39 models for the growing season to predict $\mathrm{CH}_{4}$ emissions (Table 2). The good accuracy of the averaged model (Pearson's $r=0.82$, Fig. 4) confirms the adequacy of the analyses to determine the best predictors of $\mathrm{CH}_{4}$ emissions.

Soil sulphate content was the major driver of $\mathrm{CH}_{4}$ emissions during the growing season displaying a selection probability (SP) close to 1 (Fig. 5a). It was followed, in order of importance, by soil-related traits, i.e., dry bulk density and clay content with similar prediction capacity ( $\mathrm{SP}=0.685,0.506$, respectively), and by the agronomic traits panicle density, rate of $\mathrm{N}$ fertilization and preceding grain yield ( $\mathrm{SP}=0.39,0.22,0.15$, respectively). Marginal factors were the sand content, soil organic matter, current grain yield, soil nitrogen, rate of sulphate-fertilization and plat density $(\mathrm{SP}<0.09)$. Soil sulphate and panicle density $(\beta=-0.023$ and 0.179 , respectively) negatively affected the growing season $\mathrm{CH}_{4}$ emissions (Fig. 5a, d) as opposed to the stimulatory effect of the $\mathrm{N}$ fertilization rate $(\beta=$ 


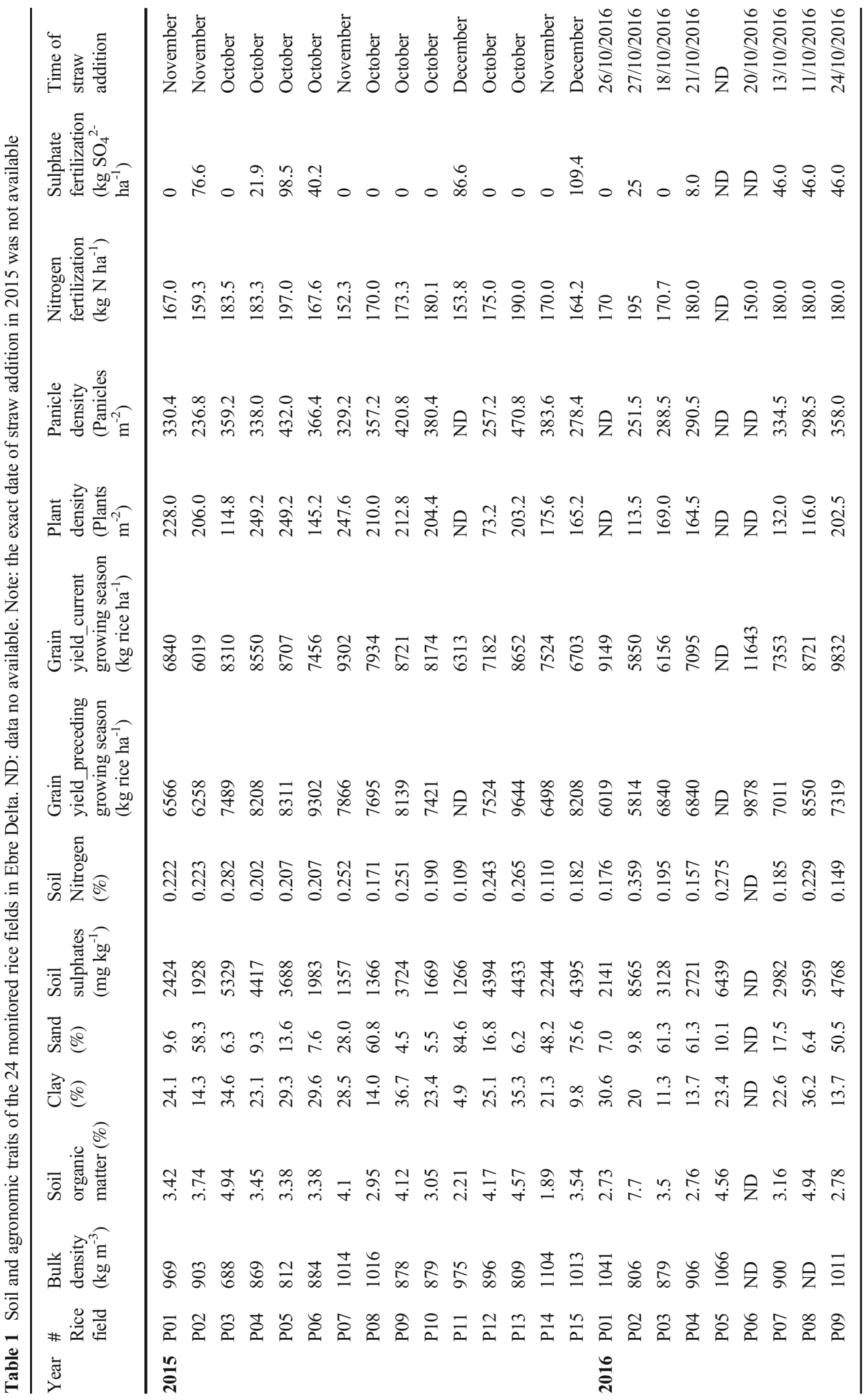




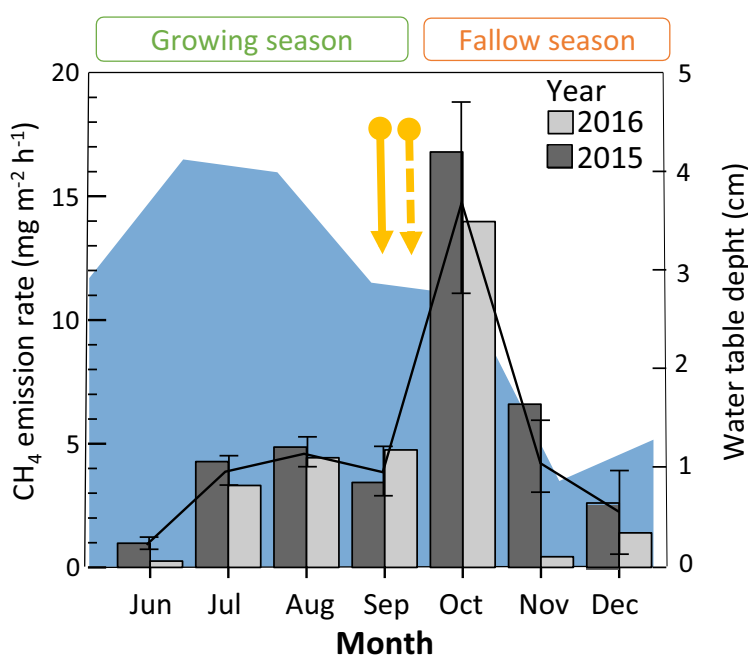

Fig. 3 Mean monthly $\mathrm{CH}_{4}$ emissions rates in rice fields in Ebre Delta over the growing (June to September) and flooded fallow (October to December) seasons in years 2015 and 2016. Columns indicate monthly mean emissions within each year and line represent the two-year monthly emission rates. Blue shaded area represents water level (monthly means across rice fields and years). Solid arrow represent harvest (September) and dashed arrow straw incorporation (in early October). Fields are sown from late April to early May (not represented in the Figure)

$0.610)$. Soils with higher dry soil bulk density and clay content emitted less $\mathrm{CH}_{4}(\beta=-0.231,-1.940$, respectively; Fig. 5b, c).

In the fallow season, 35 models were selected to predict $\mathrm{CH}_{4}$ emissions (Table 2). The good accuracy of the averaged model (Pearson's $r=0.88$ ) confirms the adequacy of the analyses to determine the best predictors of $\mathrm{CH}_{4}$ emissions (Fig. 6). The main explanatory variables $(\mathrm{SP}>0.99)$ were the grain yield of the preceding crop season (hereafter, preceding grain yield) and the rate of $\mathrm{N}$ fertilization, which both showed positive effects $(\beta=0.110,7.7672$, respectively; Fig. 7). They were followed by panicle density and current grain yield $(\mathrm{SP}=0.37)$, which negatively influenced emissions ( $\beta=-0.368,-0.017$ respectively). Soil nitrogen content, rate of sulphate fertilization, plant density, soil texture, organic matter, and dry bulk density were variables of minor importance.

\section{Drivers of total $\mathrm{CH}_{4}$ emissions}

The good accuracy (Pearson's $r=0.94$, Fig. S3) of the averaged model confirms the adequacy of the analyses to determine the best predictors of $\mathrm{CH}_{4}$ emissions. Eighteen plausible models were selected to explain annual
$\mathrm{CH}_{4}$ emissions for the growing and flooded fallow seasons combined. The most influencing variables coincided with those provided by the flooded fallow season analyses (i.e. preceding grain yield and rate of $\mathrm{N}$ fertilization), given the large contribution of $\mathrm{CH}_{4}$ during this season in relation to the total emissions (Table 2). Therefore, the results on the main drivers will be discussed for each season separately, i.e. growing and flooded fallow season, as the total emissions are explained by those in the fallow.

\section{Discussion}

On average, rice fields in the Ebre Delta emitted $262.6 \pm$ $5.9 \mathrm{~kg} \mathrm{CH}_{4}$ ha $^{-1}$ during the growing and flooded fallow season, of which almost two-thirds occurred in the flooded fallow period. The bi-modal temporal distribution of $\mathrm{CH}_{4}$ emission rates and the more cumulative emissions in the fallow than in the growing season were consistent across the years. Substantial fallow $\mathrm{CH}_{4}$ emissions are reported in other Mediterranean monocrop rice systems with winter flooded fallow and rice straw addition, contributing from 10 to $63 \%$ to the total emitted annually (Fitzgerald et al. 2000; Knox et al. 2016; Xu and Hosen 2010;). The ca. 60\% herein reported falls within the upper limit of this range, and it is particularly close to some specific years with similar straw and water management reported within both Fitzgerald's and Knox's works. Lesser fallow $\mathrm{CH}_{4}$ emissions are reported in winter flooded fields with no straw input (Fitzgerald et al. 2000; Reba et al. 2019) The overall GWP, measured as $\mathrm{kg} \mathrm{CO}_{2}$-eq ha ${ }^{-1}$, was 6466.7 $\pm 147.9 \mathrm{~kg} \mathrm{CO}_{2}$-eq ha ${ }^{-1}$, with $\mathrm{CH}_{4}$ as the main contributor whereas $\mathrm{N}_{2} \mathrm{O}$ emissions were almost negligible. Similar results were found by Wang et al. (2016); Wu et al. (2018) and Wang et al. (2019) who reported $\mathrm{N}_{2} \mathrm{O}$ emissions either several orders of magnitude lower than $\mathrm{CH}_{4}$ emissions or even negative, thus rice fields becoming small sink of $\mathrm{N}_{2} \mathrm{O}$. Given the minor role of $\mathrm{N}_{2} \mathrm{O}$ emissions on the GWP, the following discussion is focused on the main drivers of $\mathrm{CH}_{4}$ emissions.

Main drivers of $\mathrm{CH}_{4}$ emissions during the growing season

Several soil features were associated with $\mathrm{CH}_{4}$ emissions during the growing season. Overall, the information theoretic analysis of the candidate set of GLMs 
Table 2 Results from the information-theoretic framework analysis to assess the relative contribution of agronomic and environmental factors on annual, growing season and fallow $\mathrm{CH}_{4}$ emissions in the Ebre Delta rice field area. Model-averaged regression coefficients (ß) are parameter coefficients averaged by model weight across all candidate models $(\triangle \mathrm{AICc}<7)$ in which the given parameter occurs; selection probability (SP) indicates the importance of an independent variable, and parameter bias is the difference between the averaged estimates $(ß)$ and the full model coefficients. The number $(\mathrm{N})$ of candidate models $(\triangle \mathrm{AICc}<7)$ is also shown. Parameters included in the best model, in each case, are shaded in grey colour

\begin{tabular}{|c|c|c|c|c|c|c|c|c|c|}
\hline \multirow{3}{*}{ Model term } & \multicolumn{3}{|c|}{ Growing season } & \multicolumn{3}{|c|}{ Fallow season } & \multicolumn{3}{|l|}{ Annual } \\
\hline & \multicolumn{3}{|l|}{$N=39$} & \multicolumn{3}{|l|}{$N=35$} & \multicolumn{3}{|l|}{$N=18$} \\
\hline & $S P$ & $\beta$ & Bias & $S P$ & $\beta$ & Bias & $S P$ & $\beta$ & Bias \\
\hline (Intercept) & 1.00 & 417.40 & -0.76 & 1.00 & -1745.0 & -0.53 & 1.00 & -2042.7 & 0.05 \\
\hline Clay soil fraction & 0.51 & -1.94 & 1.62 & 0.06 & -0.06 & 20.62 & 0.03 & 0.05 & -46.72 \\
\hline Dry bulk soil density & 0.69 & -0.23 & -0.96 & 0.06 & 0.00 & 115.69 & 0.03 & 0.00 & -4.79 \\
\hline Grain yield_current crop season & 0.05 & -0.0001 & 56.11 & 0.37 & -0.02 & -1.88 & 0.19 & -0.01 & -4.03 \\
\hline Grain yield_preceding crop season & 0.15 & -0.002 & -1.26 & 1.00 & 0.11 & -0.27 & 1.00 & 0.12 & -0.11 \\
\hline Nitrogen content in the soil & 0.07 & -16.91 & -100.9 & 0.07 & 13.81 & -112.5 & 0.04 & 10.18 & 16.36 \\
\hline Panicle density & 0.39 & -0.18 & -2.42 & 0.37 & -0.37 & -2.53 & 0.86 & -1.41 & -0.35 \\
\hline Plant density & 0.03 & 0.00 & 338.68 & 0.09 & 0.03 & -17.65 & 0.12 & 0.08 & -10.59 \\
\hline Rate of nitrogen fertilization & 0.22 & 0.61 & -0.23 & 0.99 & 7.67 & -0.52 & 1.00 & 11.74 & -0.06 \\
\hline Rate of sulphate fertilization & 0.04 & -0.01 & -23.65 & 0.09 & 0.05 & -3.43 & 0.03 & 0.01 & -3.38 \\
\hline Sand soil fraction & 0.09 & 0.04 & -4.75 & 0.07 & -0.04 & -25.69 & 0.04 & -0.03 & -28.13 \\
\hline Soil organic matter & 0.07 & -0.97 & 69.23 & 0.06 & 0.36 & 227.63 & 0.05 & -0.10 & -143.8 \\
\hline Sulphate content in the soil & 0.98 & -0.02 & -0.34 & 0.07 & 0.00 & -25.68 & 0.73 & -0.03 & 0.16 \\
\hline
\end{tabular}

selected 38 plausible models (i.e. $\Delta \mathrm{ICc}<7$ ) to explain the variability in $\mathrm{CH}_{4}$ emissions. The best explanatory variables (SP values in Table 2) were soil sulphate, bulk

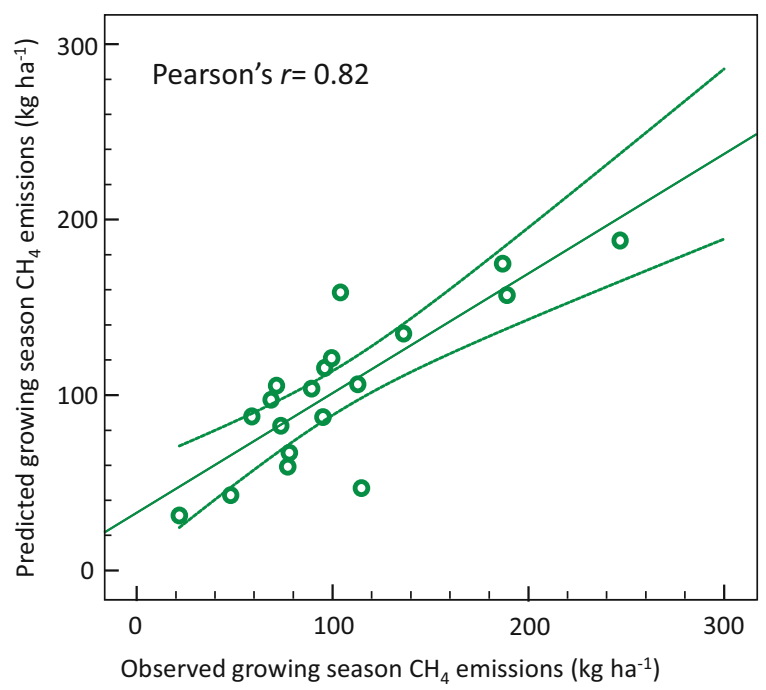

Fig. 4 Relationship between the observed and the predicted growing season $\mathrm{CH}_{4}$ emissions estimated by the GLM averaged through an information theoretic approach density, and clay concentration, all show negative relation to $\mathrm{CH}_{4}$ emissions.

Soil sulphate content is the major driver inhibition of $\mathrm{CH}_{4}$ emissions during the growing season. The observed inhibitory effect results from sulphate outcompeting methanogens as terminal electron acceptors (Ponnamperuma 1972). Despite the dominant influence of the soil sulphate content, the effect of sulphatecontaining fertilizers on $\mathrm{CH}_{4}$ emissions was minor. A number of studies demonstrate the mitigation effect of sulphate-based fertilization (Cai et al. 1997; Denier van der Gon et al. 2001; Rath et al. 2002; Minamikawa et al. 2005; Ro et al. 2011). The information- approach used here, in contraposition to the univariate analyses, allows the estimation of the relative contribution of each studied factor and suggests that, despite the demonstrated inhibitory effect of sulphates on $\mathrm{CH}_{4}$ emissions in this study and elsewhere, the mitigation potential of sulphate-based fertilizers is minor in comparison to that derived from the indigenous sulphate concentration in soils.

Both dry bulk density and soil clay content showed negative effects on $\mathrm{CH}_{4}$ emissions. Soils rich in clay emitted less $\mathrm{CH}_{4}$, which is aligned with Brye et al. 


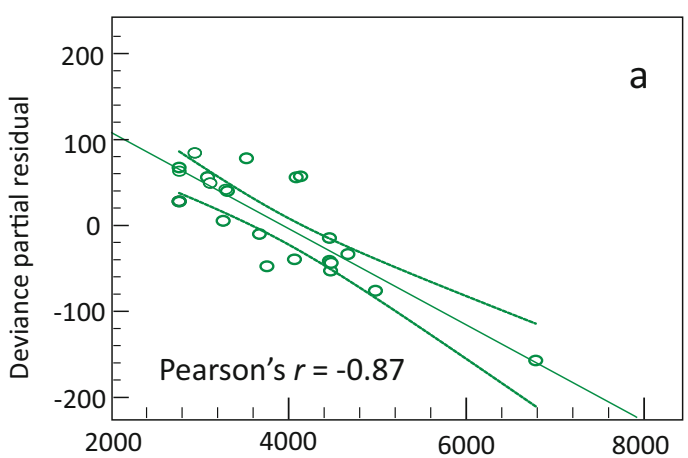

Soil sulphate content $\left(\mathrm{mg} \mathrm{kg}^{-1}\right)$

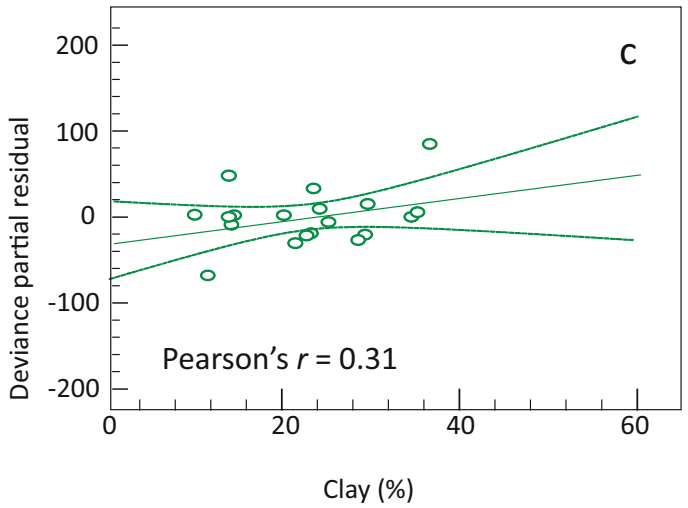

Fig. 5 Partial residual plots for the most influencing variables in growing season $\mathrm{CH}_{4}$ emission rates. Partial residuals show the effect of a given independent variable on the response after taking into account all other explanatory variables. Solid line shows the

(2013); Zhang et al. (2012); Brye et al. (2016) and Sass et al. (1994). Coarser soil texture favours the diffusivity of $\mathrm{CH}_{4}$ from the soil to the atmosphere (Brye et al. 2013)

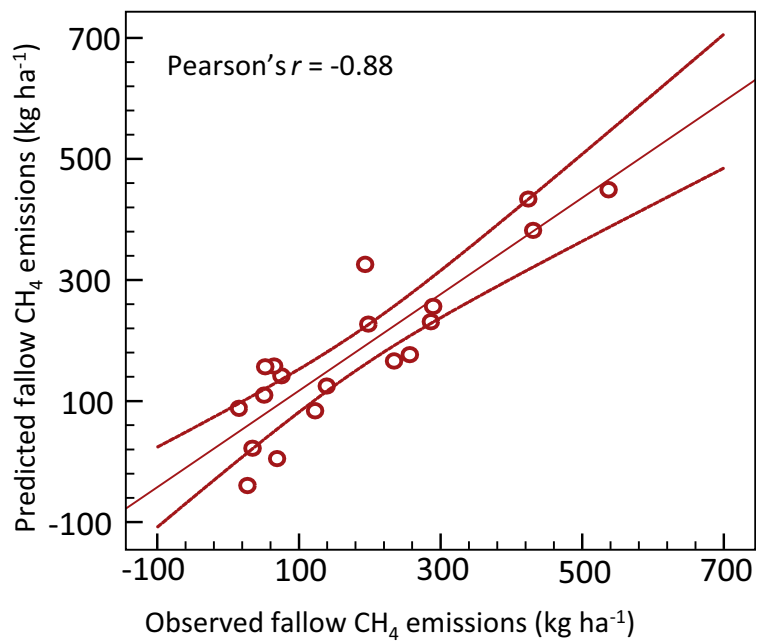

Fig. 6 Relationship between the observed and the predicted fallow $\mathrm{CH}_{4}$ emissions estimated by the GLM averaged through an information theoretic approach
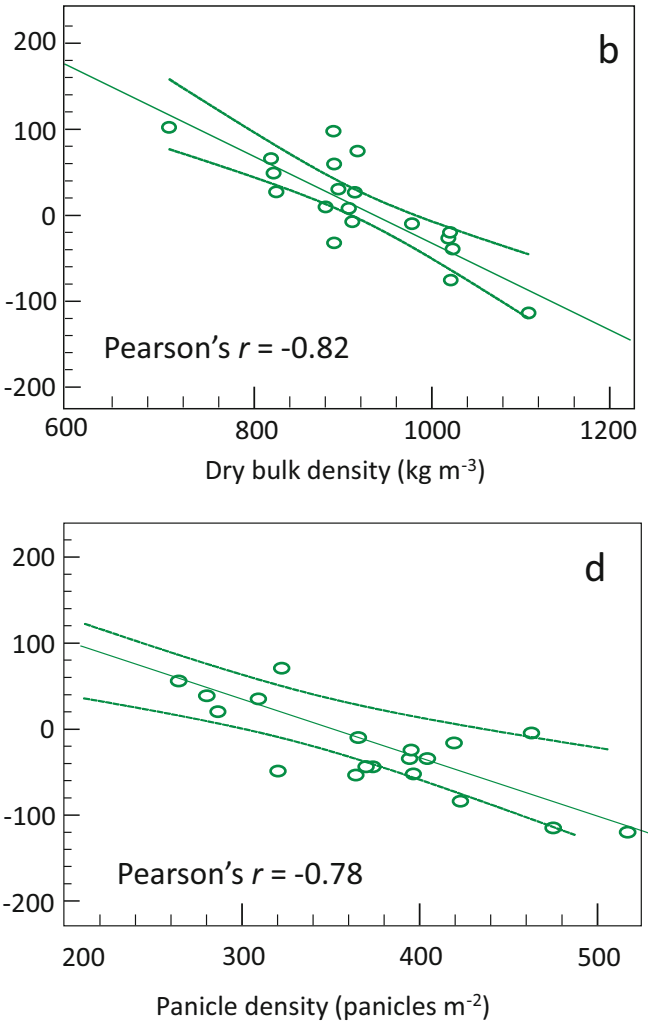

linear relationship between partial residuals and the given explanatory variable, and dashed lines are the $95 \%$ confidence interval. Pearson's correlation coefficient is shown

thus reducing residence time of the molecule in the soil (Sass and Fisher 1997) and so limiting its availability for methanotrophs (Brye et al. 2016; Smartt et al. 2016). In addition, clay particles impede the accessibility of organic matter to microbial decomposers by the formation of microaggregates (Six et al. 2002) and increase the soil ferric iron $\left(\mathrm{Fe}^{3+}\right)$ concentration (Sass et al. 1994), thus facilitating the ability of iron-reducing bacteria to outcompete methanogens (Van Bodegom et al. 2001). Dry bulk density is a pedo-transfer function of several soil properties (Aimrun and Amin 2009; Caldwell et al. 2007) influencing gas and water fluxes, biochemical reactions and processes and, subsequently, $\mathrm{CH}_{4}$ dynamics. There are different mechanisms through which high bulk density can reduce $\mathrm{CH}_{4}$ emissions, such as prolonging either the direct or plant-meditated transport of $\mathrm{CH}_{4}$ from the soil to the atmosphere (Smith et al. 2001), reducing the fraction of large pores and subsequently the availability of organic matter (Ahmad et al. 2009) or reducing the concentration of the dissolved organic carbon (DOC), the precursor of $\mathrm{CH}_{4}$ (Liu et al. 2011). 

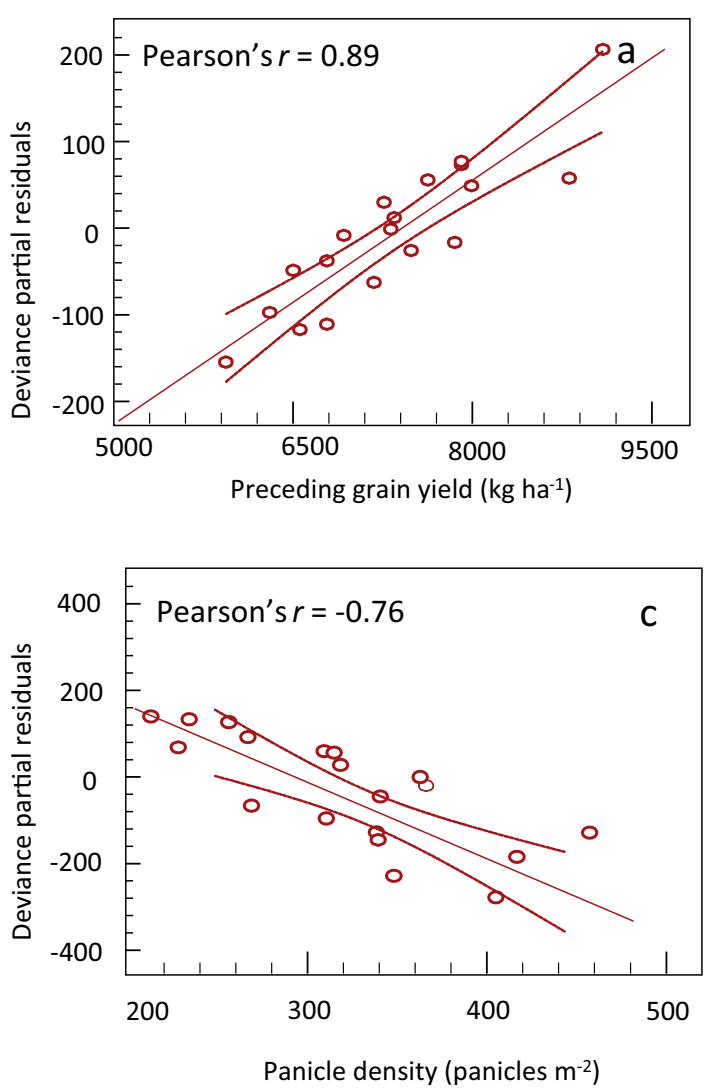

Fig. 7 Partial residual plots for the most influencing variables in fallow $\mathrm{CH}_{4}$ emission rates. Partial residuals show the effect of a given independent variable on the response after taking into account all other explanatory variables. Solid line shows the linear

To a lesser extent, panicle density, rate of $\mathrm{N}$ fertilization and grain yield from the preceding growing season (hereafter, preceding grain yield) also affected $\mathrm{CH}_{4}$ emissions during the growing season. The negative effect of both panicle density and preceding grain yield, combined with the residual effect of current grain yield and plant density suggest that favourable crop growth mitigates $\mathrm{CH}_{4}$ emissions. A fraction of the produced $\mathrm{CH}_{4}$ is consumed by methanotrophs associated with the oxidized layers of the rhizosphere (Kruger et al. 2002), which consume $80 \%$ of the total $\mathrm{CH}_{4}$ produced (Hanson and Hanson 1996). In addition, crop productivity is correlated to root biomass and thus to root oxygenated area (reviewed by Yang et al. 2012) while Gutierrez et al. (2014) found a positive correlation between the root-oxygenated area and the number of methanotrophs. According to this, we hypothesize that the observed reduction in $\mathrm{CH}_{4}$ emissions in the more productive rice fields (Fig. 5d) result from enhanced $\mathrm{CH}_{4}$ oxidative rates.
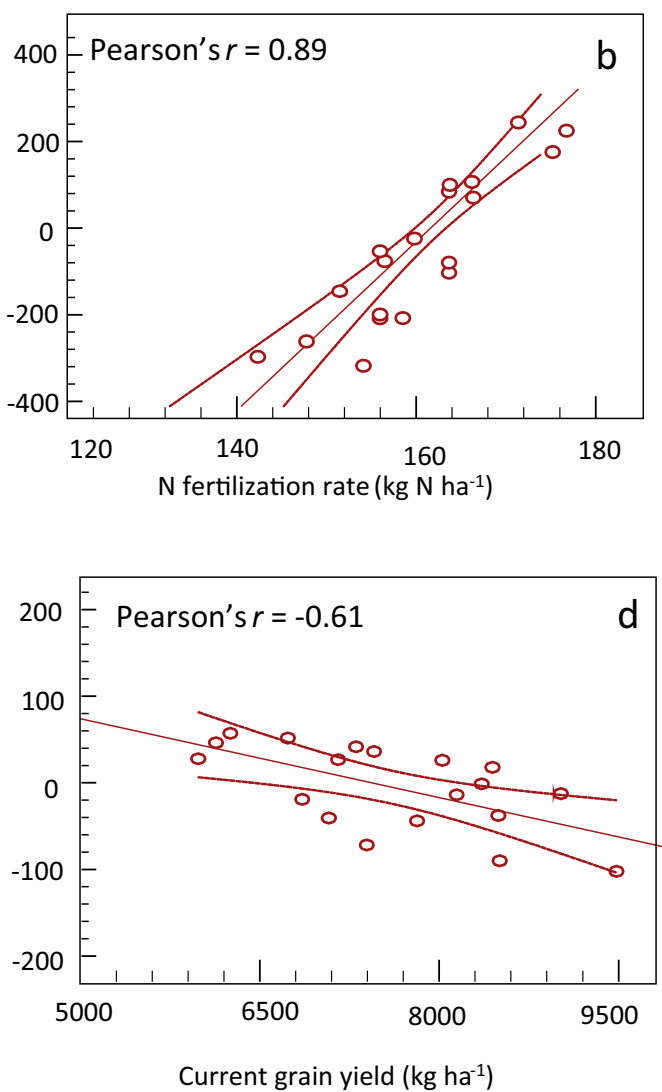

relationship between partial residuals and the given explanatory variable, and dashed lines are the $95 \%$ confidence interval. Pearson's correlation coefficient is also shown

Main drivers of $\mathrm{CH}_{4}$ emissions during the flooded fallow season

The information theoretic analysis of the candidate set of GLMs selected 38 plausible models (i.e. $\triangle \mathrm{AICc}<7$ ) to explain the variability in $\mathrm{CH}_{4}$ emissions during the flooded fallow season. Two variables were clearly selected as the best explanatory variables (SP values in Table 2), namely, preceding grain yield and nitrogen fertilization rate, both showing a positive effect on $\mathrm{CH}_{4}$ emissions. Preceding grain yield, which was used as a proxy of straw incorporated into the soil in the preceding fallow season (hereafter, preceding straw), was the main driver of $\mathrm{CH}_{4}$ emissions in the flooded fallow. Instead, straw incorporated in the ongoing season (hereafter, recently added straw) has a minor yet slight negative effect (Table 2). Several studies have described the persistence of the added straw residues (30-50\%) in the soil for one year or even longer (Neue and 
Scharpenseel 1987; Cai et al. 2018; Yan et al. 2019). Thus, one year after adding the straw into the soil, the intermediate and recalcitrant carbon-derived straw pools may persist as components of the soil organic matter (SOM) matrix (Cai et al. 2018), and the intermediate carbon pool might then account for the largest and most available carbon source for methanogenesis, representing the dominant mechanism of $\mathrm{CH}_{4}$ production. However, some previous works (Ye et al. 2014; Ye and Horwath 2017) have proposed a contrasting pattern, with more than $50 \%$ of $\mathrm{CH}_{4}$ emissions related to the recently added straw while the remaining emissions were claimed to arise from SOM. In these studies, straw was chopped or powdered into small fragments $(<1 \mathrm{~mm})$ and homogeneously distributed over the soil depth, thus favouring accessibility of the recently incorporated straw easily accessible to methanogens (Tarafdar et al. 2001). The contrasting results with our study can be explained by differences in physical and biochemical availability for the biodegradation of the recently added straw. In the Ebre Delta, resulting from wet tillage combined with straw incorporation, a set of different sizes of straw fragments (see Supplementary Fig. S2), from fine (millimetres) to coarse particles ( $>5 \mathrm{~cm}$ long), are deposited from the soil surface down to approximately $10 \mathrm{~cm}$ deep, and so are partially exposed to air due to $\mathrm{O}_{2}$ penetration by diffusion. Thus, the shallow allocation of the straw might limit its degradation by methanogenic archaea, which are strictly anaerobic, either because it is not fully integrated into the soil (air-exposed) or because anaerobic conditions are not met. The dry soil operations (soil labouring and basal fertilization operations) during the pre-sowing season (February to April) allow the full integration of straw residues into SOM matrix. In spite of this, $\mathrm{CH}_{4}$ emissions remained low over the early growing season, i.e., until July (Fig. 2) when the soil reached critical reductive conditions (redox between $-150 \mathrm{mV}$ to $-160 \mathrm{mV}$; see Martínez-Eixarch et al. 2018) for the initiation of $\mathrm{CH}_{4}$ production (Wang et al. 1993), and the crop becomes more physiologically active (Martínez-Eixarch et al. 2018). This delay in $\mathrm{CH}_{4}$ emissions up to several weeks after flooding was also reported by Brye et al. (2013).

To summarize, this pattern suggests: firstly, the predominance of growing season $\mathrm{CH}_{4}$ emissions derived from the organic matter produced from the rice plants and less from the straw-derived SOM route (Ström et al. 2003; Yuan et al. 2012) and, secondly; that straw is not decomposed and evolved to $\mathrm{CH}_{4}$ until the subsequent fallow season.

Nitrogen fertilization, along with the rate of preceding added straw, is the major driver of the fallow $\mathrm{CH}_{4}$ emissions. Despite the narrow rate of $\mathrm{N}$ fertilization (150 $\mathrm{kg} \mathrm{N} \mathrm{ha}^{-1}$ to $200 \mathrm{~kg} \mathrm{~N} \mathrm{ha}^{-1}$ ), our study provides evidence of the persist and stimulatory effect of $\mathrm{N}$ fertilization on the flooded fallow $\mathrm{CH}_{4}$ emissions. Such a persistent effect beyond the growing season have been demonstrated elsewhere (Kim et al. 2019; Datta et al. 2013) but it is in contrast with Pittelkow et al. (2013). The effect of $\mathrm{N}$ fertilization on $\mathrm{CH}_{4}$ emissions depends on the trade-off between its influence on $\mathrm{CH}_{4}$ production and oxidation (Dan et al. 2001; Xu et al. 2004) resulting from complex interactions with environmental, soil microbiota, and agronomic site-specific conditions (Banger et al. 2012). The stimulatory effect of $\mathrm{N}$ rates on both total and seasonal (growing and flooded fallow) $\mathrm{CH}_{4}$ emissions (Table 2) is in agreement with the overall trend found in two different meta-analyses conducted by Banger et al. (2012) and by Liu and Greaver (2009).

Agricultural-based options to mitigate $\mathrm{CH}_{4}$ emissions in rice fields

Understanding the key drivers of $\mathrm{CH}_{4}$ emissions provides valuable knowledge to either design more effective mitigation agronomic strategies or adapt the existing ones. The assessment of the relative contribution of agronomic factors on $\mathrm{CH}_{4}$ emissions allows for inferring their relative mitigation capacity thereby pointing out the factors that should be prioritized when designing agronomic strategies to reduce $\mathrm{CH}_{4}$ emissions. Two main implications in regard of $\mathrm{CH}_{4}$ mitigation options in the Mediterranean rice agroecosystem are derived from our study. The first one is that in Mediterranean rice growing areas such as Spain, France, and California, where winter flooding and straw return are practiced, measures to mitigate $\mathrm{CH}_{4}$ emissions in the flooded fallow season have a larger overall impact than those designed to reduce emissions in the growing season. The rice straw management and winter flooding have multiple implications on GHG emissions, crop production and ecologic functions in the rice agroecosystems. This poses the interesting challenge to find compatible solutions for mitigating $\mathrm{CH}_{4}$ emissions while preserving the agronomic (Van Groenigen et al. 2003; Pathak et al. 2006; Wang et al. 2015; MartínezEixarch et al. 2016) and environmental benefits that 
straw addition and winter flooding offer, such as carbon sequestration (Chaudhary et al. 2017) and the preservation of biodiversity (Elphick and Oring 2003; Pernollet et al. 2015). For example, alternating wetting and drying cycles (Linquist et al. 2015; Runkle et al. 2018) or implementing a single mid-season drainage (Wang et al. 2020) during the fallow season to reduce $\mathrm{CH}_{4}$ emissions while maintaining the favourable aquatic ambient for aquatic birds could be considered. In addition, limiting straw incorporation to cooler periods (Martínez-Eixarch et al. 2018) when methanogenic activity is reduced has the potential to substantially mitigate emissions and maintains the abovementioned environmental benefits.

The second agronomic implication is that enhanced rice yield may reduce $\mathrm{CH}_{4}$ emissions. Our study demonstrates that rice production and rate of nitrogen fertilization are the main agronomic controlling factors of $\mathrm{CH}_{4}$ emissions in both growing and flooded fallow season. Rice production shows an ambivalent effect on $\mathrm{CH}_{4}$ emissions with an inhibitory effect during the growing season but stimulatory in the flooded fallow season, whereas $\mathrm{N}$ rate stimulates both growing and fallow $\mathrm{CH}_{4}$ emissions. The effect of rice production on $\mathrm{CH}_{4}$ emissions is driven by two contrasting processes: more methanotrophic activity proportionally to root development and increased organic matter readily available for methanogenic communities in the soil eventually evolving to $\mathrm{CH}_{4}$ during the flooded fallow season. It is then derived that reduction of $\mathrm{CH}_{4}$ emissions via grain yield optimization could be driven by boosting root development simultaneously to favour yield partitioning to grain, i.e., increasing harvest index. Jiang et al. (2019) found that increasing harvest index (i.e., ratio of harvested grain to total shoot dry matter) could reduce $\mathrm{CH}_{4}$ emissions by ca. $4 \%$ in permanently flooded cultivated rice.

In the growing season, nitrogen stimulates the production of root exudates fuelling $\mathrm{CH}_{4}$ production whereas in the fallow season, the fraction of the remaining $\mathrm{N}$ fertilizer available in the soil can inhibit methanotrophic activity (Bodelier and Laanbroek 2004). The narrow and bidirectional associations found in this study between yield, nitrogen rates and $\mathrm{CH}_{4}$ emissions point out the improvement of nitrogen use efficiency (NUE) as a promising strategy to mitigate $\mathrm{CH}_{4}$ emissions by increasing rice productivity. NUE is determined by two components, the $\mathrm{N}$ uptake efficiency of the crop and the efficiency of $\mathrm{N}$ assimilation and remobilization of the plant to produce grain. The enhancement of these two components results in limiting soil $\mathrm{N}$ availability (Che et al. 2015; Guo et al. 2017) and favouring harvest index (Huang et al. 2018), which, according to our study, are two necessary features to reduce $\mathrm{CH}_{4}$ emissions. There are few studies testing the hypothesis that enhanced NUE can reduce $\mathrm{CH}_{4}$ emissions in permanently flooded rice fields (Liu et al. 2015; Adviento-Borbe and Linquist 2016; Zhu et al. 2016) and yet they provide contrasting results because either the tested practices are different (i.e., plant density, $\mathrm{N}$ placement, $\mathrm{N}$ rates) or the rice cropping systems also differ. Taking all this together, we think that NUE enhancement is an unexplored promising win-win strategy to both mitigate $\mathrm{CH}_{4}$ emissions and improve rice production that should be further explored on a site-specific crop context to address the high complexity of the rice agroecosystems.

Before concluding, some considerations on the sampling strategy. This is a multi-site study conceived to assess both the temporal pattern of GHG emissions and their main drivers so that covering the spatial environmental and agronomic variability of the whole area of rice cultivation was crucial for the pursue of this objective. However, multi-site sampling was at the expense of intense sampling rate, which was conducted monthly, thus less frequently than the recommended weekly or biweekly samplings (Minamikawa et al. 2012). Nevertheless, the consistent temporal pattern, the narrow range of variation of the emission rates provides confidence in the reliability of the results and the derived conclusions.

\section{Conclusions}

This study argued that the main drivers of cumulative $\mathrm{CH}_{4}$ emissions are different in the growing than in the fallow seasons. Edaphic factors exert more influence on $\mathrm{CH}_{4}$ emissions during the growing season whereas agronomic factors have a higher impact in the fallow season. In the growing season, soil sulphate content, followed by bulk density and clay content are the main emission drivers. The effect of the inherent soil sulphate in lowering $\mathrm{CH}_{4}$ emissions surpass that obtained by sulphate-based fertilizers, which resulted in only minor decreases. Soils with higher bulk density and clay content emit less $\mathrm{CH}_{4}$. In the fallow season, the rate of both straw incorporated in the preceding crop (rather than that added in the ongoing season) and nitrogen fertilizer 
are the major controlling factors. The stimulating effect of Nitrogen fertilization on $\mathrm{CH}_{4}$ emissions is larger in the fallow season in relation to the growing season. Of all the agronomic factors analysed in this study, rice productivity and nitrogen fertilization rates are those with the most influence on $\mathrm{CH}_{4}$ emissions, so that effective mitigation strategies should include them.

Supplementary Information The online version contains supplementary material available at https://doi.org/10.1007/s11104020-04809-5.

Acknowledgements This work was supported by the European Union through the Life + Environmental Policy and Governance, project entitled Pilot project for adaptation and mitigation measures for Climate Change in Ebre Delta (Life13 ENV/ES/001182); and by the Ministry of Economy and Competitiveness through the National Institute for Agricultural and Food Research and Technology (INIA) Spanish, project entitled Mitigation and adaptation to climate change in coastal rice fields (RTA2014-00058-C03-03). The support of the CERCA Programme / Generalitat de Catalunya is also acknowledged. The funders had no role in study design, data collection and analysis, decision to publish, or preparation of the manuscript. We also acknowledge the logistic support provided by the Kellogg's Origins Program and the farmers within this program for authorizing us to sample in their fields.

The authors would like to thank Lluís Jornet, Pep Cabanes and David Mateu (IRTA-Marine and continental waters), Andrea Bertomeu (IRTA- Extensive crops) and, Bea Grau, Inma Funes and Eulàlia Serra (IRTA- Fruticulture) for their technical support and field assistance.

Open Access This article is licensed under a Creative Commons Attribution 4.0 International License, which permits use, sharing, adaptation, distribution and reproduction in any medium or format, as long as you give appropriate credit to the original author(s) and the source, provide a link to the Creative Commons licence, and indicate if changes were made. The images or other third party material in this article are included in the article's Creative Commons licence, unless indicated otherwise in a credit line to the material. If material is not included in the article's Creative Commons licence and your intended use is not permitted by statutory regulation or exceeds the permitted use, you will need to obtain permission directly from the copyright holder. To view a copy of this licence, visit http://creativecommons.org/licenses/by/4.0/.

\section{References}

Adviento-Borbe MAA, Linquist B (2016) Assessing fertilizer N placement on $\mathrm{CH}_{4}$ and $\mathrm{N}_{2} \mathrm{O}$ emissions in irrigated rice systems. Geoderma 266:40-45

Ahmad S, Li C, Dai G, Zhan M, Wang J, Pan S, Cao C (2009) Greenhouse gas emission from direct seeding paddy field under different rice tillage systems in Central China. Soil Tillage Res 106:54-61

Aimrun W, Amin MSM (2009) Pedo-transfer function for saturated hydraulic conductivity of lowland paddy soils. Paddy Water Environ 7:217-225

Alhaj Hamoud Y, Wang Z, Guo X, Shaghaleh H, Sheteiwy M, Chen S, Qiu R, Elbashier M (2019) Effect of irrigation regimes and soil texture on the potassium utilization efficiency of Rice. Agronomy 9:100

Altor AE, Mitsch WJ (2008) Pulsing hydrology, methane emissions and carbon dioxide fluxes in created marshes: a 2-year ecosystem study. Wetlands 28:423-438

Banger K, Tian H, Lu C (2012) Do nitrogen fertilizers stimulate or inhibit methane emissions from rice fields? Glob Chang Biol 18:3259-3267

Banik A, Sen M, Sen SP (1996) Effects of inorganic fertilizers and micronutrients on methane production from wetland rice (Oryza sativa L.). Biol Fertil Soils 21:319-322

Bodelier PL, Laanbroek HJ (2004) Nitrogen as a regulatory factor of methane oxidation in soils and sediments. FEMS Microbiol Ecol 47:265-277

Brye KR, Rogers CW, Smartt AD, Norman RJ (2013) Soil texture effects on methane emissions from direct-seeded, delayedflood Rice production in Arkansas. Soil Sci 178:519-529

Brye KR, Nalley LL, Tack JB, Dixon BL, Barkley AP, Rogers CW, Smartt AD, Norman RJ, Jagadish KSV (2016) Factors affecting methane emissions from rice production in the lower Mississippi river valley, USA. Geoderma Regional 7: 223-229

Cai ZC, Xing GX, Yan XY, Xu H, Tsuruta H, Yagi K, Minami K (1997) Methane and nitrous oxide emissions from rice paddy fields as affected by nitrogen fertilizers and water management. Plant Soil 196:7-14

Cai Z, Shan Y, Xu H (2007) Effects of nitrogen fertilization on $\mathrm{CH}_{4}$ emissions from rice fields. Soil Science and Plant Nutrition 53:353-361

Cai A, Liang G, Zhang X, Zhang W, Li L, Rui Y, Xu M, Luo Y (2018) Long-term straw decomposition in agro-ecosystems described by a unified three-exponentiation equation with thermal time. Sci Total Environ 636:699-708

Caldwell PV, Vepraskas MJ, Gregory JD (2007) Physical properties of natural organic soils in Carolina bays of the southeastern United States. Soil Sci Soc Am J 71:1051-1057

Carlson KM, Gerber JS, Mueller ND, Herrero M, MacDonald GK, Brauman KA, Havlik P, Oconnell CS, Johnson JA, Saatchi S, West PC (2017) Greenhouse gas emissions intensity of global croplands. Nature Clim Change 7:63-68

Chaudhary S, Dheri GS, Brar BS (2017) Long-term effects of NPK fertilizers and organic manures on carbon stabilization and management index under rice-wheat cropping system. Soil Tillage Res 166:59-66

Che S-g, Zhao B-q, Li Y-t, Yuan L, Li W, Lin Z-a, Hu S-w, Shen B (2015) Review grain yield and nitrogen use efficiency in rice production regions in China. J Integr Agric 14:24562466

Cicerone RJ, Shetter JD (1981) Sources of atmospheric methane: measurements in rice paddies and a discussion. Journal of Geophysical Research: Oceans 86:7203-7209

Conrad R (2007) Microbial ecology of methanogens and methanotrophs. Adv Agron 96:1-63 
Dan JG, Kruger M, Frenzel P, Conrad R (2001) Effect of a late season urea fertilization on methane emission from a rice field in Italy. Agric Ecosyst Environ 83:191-199

Datta A, Santra SC, Adhya TK (2013) Effect of inorganic fertilizers $(\mathrm{N}, \mathrm{P}, \mathrm{K})$ on methane emission from tropical rice field of India. Atmos Environ 66:123-130

Denier van der Gon HA, van Bodegom PM, Wassmann R, Lantin RS, Metra-Corton TM (2001) Sulfate-containing amendments to reduce methane emissions from rice fields: mechanisms, effectiveness and costs. Mitig Adapt Strateg Glob Chang 6:71-89

Dou F, Soriano J, Tabien RE, Chen K (2016) Soil texture and cultivar effects on Rice (Oryza sativa, L.) grain yield, yield components and water productivity in three water regimes. PLoS One 11:e0150549-e150549

Elphick CS, Oring LW (2003) Conservation implications of flooding rice fields on winter waterbird communities. Agric Ecosyst Environ 94:17-29

Fitzgerald GJ, Scow KM, Hill JE (2000) Fallow season straw and water management effects on methane emissions in California rice. Glob Biogeochem Cycles 14:767-776

Guo J, Hu X, Gao L, Xie K, Ling N, Shen Q, Hu S, Guo S (2017) The rice production practices of high yield and high nitrogen use efficiency in Jiangsu, China. Sci Rep 7:2101

Gutierrez J, Atulba SL, Kim G, Kim PJ (2014) Importance of rice root oxidation potential as a regulator of $\mathrm{CH}_{4}$ production under waterlogged conditions. Biol Fertil Soils 50:861-868

Hanson RS, Hanson TE (1996) Methanotrophic bacteria. Microbiol Rev 60:439-471

Hatala JA, Detto M, Baldocchi DD (2012) Gross ecosystem photosynthesis causes a diurnal pattern in methane emission from rice. Geophys Res Lett 39

Huang, S., Zhao, C., Zhang, Y., Wang, C., 2018. Nitrogen use efficiency in rice. Nitrogen in Agriculture-Updates

IPCC (2019): Summary for Policymakers. In: Climate Change and Land: an IPCC special report on climate change, desertification, land degradation, sustainable land management, food security, and greenhouse gas fluxes in terrestrial ecosystems [P.R. Shukla, J. Skea, E. Calvo Buendia, V. MassonDelmotte, H.- O. Pörtner, D. C. Roberts, P. Zhai, R. Slade, S. Connors, R. van Diemen, M. Ferrat, E. Haughey, S. Luz, S. Neogi, M. Pathak, J. Petzold, J. Portugal Pereira, P. Vyas, E. Huntley, K. Kissick, M. Belkacemi, J. Malley, (eds.)]. In press

Jia ZJ, Cai ZC, Xu H, Tsuruta H (2002) Effects of rice cultivars on methane fluxes in a paddy soil. Nutr Cycl Agroecosyst 64: 87-94

Jiang Y, van Groenigen KJ, Huang S, Hungate BA, van Kessel C, Hu S, Zhang J, Wu L, Yan X, Wang L (2017) Higher yields and lower methane emissions with new rice cultivars. Glob Chang Biol 23:4728-4738

Jiang Y, Qian H, Wang L, Feng J, Huang S, Hungate BA, van Kessel C, Horwath WR, Zhang X, Qin X (2019) Limited potential of harvest index improvement to reduce methane emissions from rice paddies. Glob Chang Biol 25:686-698

Kim GW, Gutierrez-Suson J, Kim PJ (2019) Optimum N rate for grain yield coincides with minimum greenhouse gas intensity in flooded rice fields. Field Crops Research 237:23-31

Knox SH, Matthes JH, Sturtevant C, Oikawa PY, Verfaillie J, Baldocchi D (2016) Biophysical controls on interannual variability in ecosystem-scale $\mathrm{CO} 2$ and $\mathrm{CH}_{4}$ exchange in a
California rice paddy. Journal of Geophysical ResearchBiogeosciences 121:978-1001

Kritee K, Nair D, Zavala-Araiza D, Proville J, Rudek J, Adhya TK, Loecke T, Esteves T, Balireddygari S, Dava O, Ram KSR, Abhilash M, Murugan D, Ramakrishna V, Anandaraj D, Athiyaman D, Reddy M, Ahuja R, Hamburg SP (2018) High nitrous oxide fluxes from rice indicate the need to manage water for both long- and short-term climate impacts. Procedeeings of the National Academy of Sciences of the United States of America 39:9720-9725

Kruger M, Eller G, Conrad R, Frenzel P (2002) Seasonal variation in pathways of $\mathrm{CH}_{4}$ production and in $\mathrm{CH}_{4}$ oxidation in rice fields determined by stable carbon isotopes and specific inhibitors. Glob Chang Biol 8:265-280

Laanbroek HJ (2010) Methane emission from natural wetlands: interplay between emergent macrophytes and soil microbial processes. A mini-review. Annals of Botany 105:141-153

Lagomarsino A, Agnelli A.E, Linquist B., Adviento-Borbe MA., Agnelli A, Gavina G., Ravaglia, S., Ferrara, R.M., 2016. Alternate wetting and drying of rice reduced $\mathrm{CH}_{4}$ emissions but triggered $\mathrm{N}_{2} \mathrm{O}$ peaks in a clayey soil of Central Italy. Pedosphere 26(4):533-548

Linquist BA, Anders MM, Adviento-Borbe MA, Chaney RL, Nalley LL, da Rosa EF, van Kessel C (2015) Reducing greenhouse gas emissions, water use, and grain arsenic levels in rice systems. Glob Change Biol 21:407-417

Linquist BA, Marcos M, Adviento-Borbe MA, Anders M, Harrell D, Linscombe S, Reba ML, Runkle BR, Tarpley L, Thomson A (2018) Greenhouse gas emissions and management practices that affect emissions in US rice systems. J Environ Qual 47:395-409

Liu L, Greaver TL (2009) A review of nitrogen enrichment effects on three biogenic GHGs: the $\mathrm{CO} 2$ sink may be largely offset by stimulated $\mathrm{N}_{2} \mathrm{O}$ and $\mathrm{CH}_{4}$ emission. Ecol Lett 12:11031117

Liu D, Ding W, Jia Z, Cai Z (2011) Relation between methanogenic archaea and methane production potential in selected natural wetland ecosystems across China. Biogeosciences 8: 329-338

Liu YL, Zhou ZQ, Zhang XX, Xu X, Chen H, Xiong ZQ (2015) Net global warming potential and greenhouse gas intensity from the double rice system with integrated soil-crop system management: a three-year field study. Atmos Environ 116: 92-101

Lu YH, Conrad R (2005) In situ stable isotope probing of methanogenic archaea in the rice rhizosphere. Science 309:1088-1090

Maggini R, Lehmann A, Zimmermann NE, Guisan A (2006) Improving generalized regression analysis for the spatial prediction of forest communities. J Biogeogr 33:1729-1749

Martínez-Eixarch M, Curcó A, Ibáñez C (2016) Effects of agrienvironmental and organic rice farming on yield and macrophyte community in Mediterranean paddy fields. Paddy Water Environ: $1-12$

Martínez-Eixarch M, Alcaraz C, Viñas M, Noguerol J, Aranda X, Prenafeta-Boldú F, la Vega Saldaña-De J, Català M, Ibáñez C (2018) Neglecting the fallow season can significantly underestimate annual methane emissions in Mediterranean rice fields. PLoS One 13:e0198081-e0198081

Matías J, Cruz V, García A, González D (2019) Evaluation of rice straw yield, fibre composition and collection under 
Mediterranean conditions. Acta Technologica Agriculturae 22:43-47

Minamikawa K, Sakai N, Hayashi H (2005) The effects of ammonium sulfate application on methane emission and soil carbon content of a paddy field in Japan. Agric Ecosyst Environ 107:371-379

Minamikawa K, Yagi K, Tokida T, Sander BO, Wassmann R (2012) Appropriate frequency and time of day to measure methane emissions from an irrigated rice paddy in Japan using the manual closed chamber method. Greenhouse Gas Measurement and Management 2:118-128

Nauhaus K, Treude T, Boetius A, Krüger M (2005) Environmental regulation of the anaerobic oxidation of methane: a comparison of ANME-I and ANME-II communities. Environ Microbiol 7:98-106

Neue HU, Scharpenseel HW (1987) Decomposition pattern of 14C-labeled rice straw in aerobic and submerged rice soils of the Philippines. Sci Total Environ 62:431-434

Pathak H, Singh R, Bhatia A, Jain N (2006) Recycling of rice straw to improve wheat yield and soil fertility and reduce atmospheric pollution. Paddy Water Environ 4:111-117

Pernollet CA, Simpson D, Gauthier-Clerc M, Guillemain M (2015) Rice and duck, a good combination? Identifying the incentives and triggers for joint rice farming and wild duck conservation. Agric Ecosyst Environ 214:118-132

Pittelkow CM, Adviento-Borbe MA, Hill JE, Six J, van Kessel C, Linquist BA (2013) Yield-scaled global warming potential of annual nitrous oxide and methane emissions from continuously flooded rice in responseto nitrogen input. Agric Ecosyst Environ 177:10-20

Ponnamperuma FN (1972) The chemistry of submerged soils. Adv Agron 24:29-96

Rath AK, Swain B, Ramakrishnan B, Panda D, Adhya TK, Rao VR, Sethunathan N (1999) Influence of fertilizer management and water regime on methane emission from rice fields. Agric Ecosyst Environ 76:99-107

Rath AK, Ramakrishnan B, Sethunathan N (2002) Effect of application of ammonium thiosulphate on production and emission of methane in a tropical rice soil. Agric Ecosyst Environ 90:319-325

Reba ML, Fong BN, Rijal I (2019) Fallow season $\mathrm{CO}_{2}$ and $\mathrm{CH}_{4}$ fluxes from US mid-south rice-waterfowl habitats. Agric For Meteorol 279:107709

Ro S, Seanjan P, Tulaphitak T, Inubushi K (2011) Sulfate content influencing methane production and emission from incubated soil and rice-planted soil in Northeast Thailand. Soil Science and Plant Nutrition 57:833-842

Runkle BR, Suvočarev K, Reba ML, Reavis CW, Smith SF, Chiu YL, Fong B (2018) Methane emission reductions from the alternate wetting and drying of rice fields detected using the eddy covariance method. Environmental science \& technology 53(2):671-681

Sass RL, Fisher FM (1997) Methane emissions from rice paddies: a process study summary. Nutr Cycl Agroecosyst 49:119-127

Sass RL, Fisher FM, Lewis ST, Jund MF, Turner FT (1994) Methane emissions from rice fields - effect of soil properties. Glob Biogeochem Cycles 8:135-140

Schaefer H, Fletcher SEM, Veidt C, Lassey KR, Brailsford GW, Bromley TM, Dlugokencky EJ, Michel SE, Miller JB, Levin I, Lowe DC, Martin RJ, Vaughn BH, White JWC (2016) A 21st-century shift from fossil-fuel to biogenic methane emissions indicated by $<$ sup $>13</$ sup $>\mathrm{CH}<$ sub $>4</$ sub $>$. Science 352:80-84

Shang Q, Yang X, Gao C, Wu P, Liu J, Xu Y, Shen Q, Zou J, Guo $S$ (2011) Net annual global warming potential and greenhouse gas intensity in Chinese double rice-cropping systems: a 3-year field measurement in long-term fertilizer experiments. Glob Chang Biol 17:2196-2210

Six J, Conant R, Paul EA, Paustian K (2002) Stabilization mechanisms of soil organic matter: implications for $\mathrm{C}$-saturation of soils. Plant Soil 241:155-176

Smartt AD, Brye KR, Rogers CW, Norman RJ, Gbur EE, Hardke JT, Roberts TL (2016) Characterization of methane Emissions from Rice production on a clay soil in Arkansas. Soil Sci 181:57-67

Smith P, Goulding KW, Smith KA, Powlson DS, Smith JU, Falloon P, Coleman K (2001) Enhancing the carbon sink in European agricultural soils: including trace gas fluxes in estimates of carbon mitigation potential. Nutr $\mathrm{Cycl}$ Agroecosyst 60:237-252

Smith P, Clark H, Dong H, Elsiddig E, Haberl H, Harper R, House J, Jafari M, Masera O, Mbow C (2014) Agriculture, forestry and other land use (AFOLU)

Spanish Ministry of Agriculture, Food and Environment. Distribución de la supeficie y produción de arroz en España por Comunidades Autónomas. Retrieved from https://www. mapa.gob.es/es/agricultura/temas/produccionesagricolas/distribsuperf_prodarrozenespanaporccaa_tcm30135393.pdf. Accessed 24 Dec 2020

Ström L, Ekberg A, Mastepanov M, Røjle Christensen T (2003) The effect of vascular plants on carbon turnover and methane emissions from a tundra wetland. Glob Change Biol 9:11851192

Tabachnick BG, Fidell LS, Ullman JB (2007) Using multivariate statistics. Pearson Boston, MA

Tarafdar JC, Meena SC, Kathju S (2001) Influence of straw size on activity and biomass of soil microorganisms during decomposition. Eur J Soil Biol 37:157-160

Tokida T, Adachi M, Cheng W, Nakajima Y, Fumoto T, Matsushima M, Nakamura H, Okada M, Sameshima R, Hasegawa $\mathrm{T}$ (2011) Methane and soil $\mathrm{CO}_{2}$ production from current-season photosynthates in a rice paddy exposed to elevated $\mathrm{CO}_{2}$ concentration and soil temperature. Glob Chang Biol 17:3327-3337

Van Bodegom P, Goudriaan J, Leffelaar P (2001) A mechanistic model on methane oxidation in a rice rhizosphere. Biogeochemistry 55:145-177

Van Groenigen J, Burns E, Eadie J, Horwath W, Van Kessel C (2003) Effects of foraging waterfowl in winter flooded rice fields on weed stress and residue decomposition. Agric Ecosyst Environ 95:289-296

Wang ZP, Delaune RD, Masscheleyn PH, Patrick WH (1993) Soil redox and $\mathrm{Ph}$ effects on methane production in a flooded rice soil. Soil Sci Soc Am J 57:382-385

Wang W, Lai DYF, Wang C, Pan T, Zeng C (2015) Effects of rice straw incorporation on active soil organic carbon pools in a subtropical paddy field. Soil Tillage Res 152:8-16

Wang W, Wu X, Chen A, Xie X, Wang Y, Yin C (2016) Mitigating effects of ex situ application of rice straw on $\mathrm{CH}$ 4 and $\mathrm{N} 2 \mathrm{O}$ emissions from paddy-upland coexisting system. Sci Rep 6:37402 
Wang W, Chen C, Wu X, Xie K, Yin C, Hou H, Xie X (2019) Effects of reduced chemical fertilizer combined with straw retention on greenhouse gas budget and crop production in double rice fields. Biol Fertil Soils 55:89-96

Wang H, Zhang Y, Zhang Y, McDaniel MD, Sun L, Su W, Fan X, Liu S, Xiao X (2020) Water-saving irrigation is a 'winwin'management strategy in rice paddies-with both reduced greenhouse gas emissions and enhanced water use efficiency. Agric Water Manag 228:105889

Wassmann R, Schütz H, Papen H, Rennenberg H, Seiler W, Aiguo D, Renxing S, Xingjian S, Mingxing W (1993) Quantification of methane emissions from Chinese rice fields (Zhejiang Province) as influenced by fertilizer treatment. Biogeochemistry 20:83-101

Watanabe I, Hashimoto T, Shimoyama A (1997) Methaneoxidizing activities and methanotrophic populations associated with wetland rice plants. Biol Fertil Soils 24:261-265

Weishampel, P., Kolka, R., 2008. Measurement of methane fluxes from terrestrial landscapes using static, non-steady state enclosures. Field measurements for forest carbon monitoring. Springer, pp. 163-170

Wu X, Wang W, Xie X, Yin C, Hou H, Yan W, Wang G (2018) Net global warming potential and greenhouse gas intensity as affected by different water management strategies in Chinese double rice-cropping systems. Sci Rep 8:1-9

Xu H, Hosen Y (2010) Effects of soil water content and rice straw incorporation in the fallow season on $\mathrm{CH}_{4}$ emissions during fallow and the following rice-cropping seasons. Plant Soil 335(1-2):373-383

$\mathrm{Xu}$ ZJ, Zheng XH, Wang YS, Han SH, Huang Y, Zhu JG, Butterbach-Bahl K (2004) Effects of elevated CO and N fertilization on $\mathrm{CH}$ emissions from paddy rice fields. Global Biogeochem Cy 18
Yan X, Yagi K, Akiyama H, Akimoto H (2005) Statistical analysis of the major variables controlling methane emission from rice fields. Glob Chang Biol 11:1131-1141

Yan C, Yan S-S, Jia T-Y, Dong S-K, Ma C-M, Gong Z-P (2019) Decomposition characteristics of rice straw returned to the soil in Northeast China. Nutr Cycl Agroecosyst 114:211-224

Yang J-c, Zhang H, Zhang J-h (2012) Root morphology and physiology in relation to the yield formation of Rice. J Integr Agric 11:920-926

Ye R, Horwath WR (2017) Influence of rice straw on priming of soil $\mathrm{C}$ for dissolved organic $\mathrm{C}$ and $\mathrm{CH}_{4}$ production. Plant and Soil:1-11

Ye Y, Liang X, Chen Y, Li L, Ji Y, Zhu C (2014) Carbon, nitrogen and phosphorus accumulation and partitioning, and $\mathrm{C}: \mathrm{N}: \mathrm{P}$ stoichiometry in late-season Rice under different water and nitrogen managements. PLoS One 9:e101776

Yuan Q, Pump J, Conrad R (2012) Partitioning of CH4 and CO2 Production Originating from Rice Straw, Soil and Root Organic Carbon in Rice Microcosms. Plos One 7

Zhang Y, Su S, Zhang F, Shi R, Gao W (2012) Characterizing spatiotemporal dynamics of methane emissions from rice paddies in Northeast China from 1990 to 2010. PLoS One 7:e29156

Zhu XC, Zhang J, Zhang ZP, Deng AX, Zhang WJ (2016) Dense planting with less basal nitrogen fertilization might benefit rice cropping for high yield with less environmental impacts. Eur J Agron 75:50-59

Publisher's note Springer Nature remains neutral with regard to jurisdictional claims in published maps and institutional affiliations. 